Trinity University

Digital Commons@ Trinity

Chemistry Faculty Research

Chemistry Department

$12-2013$

\title{
Effects of Sequence Context on the Binding of Tryptophan-Containing Peptides by the Cucurbit[8] uril-Methyl Viologen Complex
}

Omar A. Ali

TrinityUniversity, oali@trinity.edu

Eric M. Olson

TrinityUniversity, eolson@trinity.edu

Adam R. Urbach

Trinity University, aurbach@trinity.edu

Follow this and additional works at: https://digitalcommons.trinity.edu/chem_faculty

Part of the Chemistry Commons

\section{Repository Citation}

Ali, O. A., Olson, E. M., \& Urbach, A. R. (2013). Effects of sequence context on the binding of tryptophan-containing peptides by the cucurbit[8] uril-methyl viologen complex. Supramolecular Chemistry, 25(12), 863-868. doi: 10.1080/10610278.2013.810338

This Post-Print is brought to you for free and open access by the Chemistry Department at Digital Commons @ Trinity. It has been accepted for inclusion in Chemistry Faculty Research by an authorized administrator of Digital Commons @ Trinity. For more information, please contact jcostanz@trinity.edu. 


\title{
Effects of Sequence Context on the Binding of Tryptophan-Containing Peptides by the Cucurbit[8]uril-Methyl Viologen Complex
}

\author{
Omar A. Ali, Eric M. Olson, and Adam R. Urbach* \\ Department of Chemistry, Trinity University, San Antonio, TX 78212
}

* To whom correspondence should be addressed: aurbach@trinity.edu

\begin{abstract}
This paper describes a novel assay for measuring the relative extent of peptide binding in a large parallel format, and the use of this assay to explore the effects of sequence context on the binding of tryptophan (Trp)-containing peptides by the synthetic receptor comprising the noncovalent complex between cucurbit[8]uril and methyl viologen (i.e., Q8•MV). The extent of quenching of Trp fluorescence upon binding to $\mathrm{Q} 8 \bullet \mathrm{MV}$ was used to measure the relative extent of binding and thus the relative affinities of 104 Trp-containing peptides, in parallel, using a fluorescence plate reader. This study resulted in the remarkable observation that the identity of the amino acid residues at positions adjacent to the Trp binding site has little if any influence on the binding affinity. This finding suggests that $\mathrm{Q} 8 \bullet \mathrm{MV}$ should be effective for the recognition of Trp residues within a broad range of peptide sequences.
\end{abstract}

Keywords: cucurbit[8]uril, viologen, tryptophan, peptide, assay 


\section{Introduction}

Synthetic receptors that can bind to peptides with well-defined affinities and specificities would have enormous value for biomedical science and technology. The recognition properties of natural protein receptors may depend on specificity for a certain type of amino acid residue (e.g., N-recognins, kinases, endopeptidases) (1-3) or a certain type of peptide sequence or small protein fragment (e.g., antibodies, cell-surface receptors). In any case, it is important to understand how the sequence environment (i.e., neighboring residues) influences binding. Several synthetic receptors have been shown to bind peptides and proteins (4-17), but in the majority of cases, these receptors are known to bind to a single type of residue, and the effects of sequence context are understood to a limited extent. This paper describes the effects of sequence context on the interactions of tryptophan-containing peptides with the synthetic receptor, cucurbit[8]uril (Q8), and a method that enables this determination in a rapid and parallel fashion.

Q8 is a tire-shaped, macrocyclic oligomer of bis(methylene)-bridged glycoluril, whose hydrophobic inner space and polar rims drive the inclusion of cationic, organic, small molecules $(18,19)$. Compared to other cucurbit[n]urils, Q8 has been studied extensively for its ability to bind two guests simultaneously in aqueous solution (20-29). Much of our work with Q8 has focused on the molecular recognition of peptides (30-36). We have shown that, when bound to methyl viologen (MV) or tetramethyl benzobis(imidazolium) as the first guest, Q8 binds to peptides containing tryptophan (Trp) with preference for Trp at the N-terminal position (Trp-Gly-Gly; Gly = glycine) versus nonterminal (Gly-TrpGly) or C-terminal (Gly-Gly-Trp) positions (Figure 1) $(32,36)$. Others have used this approach for peptide separation and protein assays (37-40). We are interested in the efficacy of peptide recognition across a broad array of sequence contexts. Specifically, we want to know how residues adjacent to the Trp 
binding site may influence the binding of $\mathrm{Q} 8 \bullet \mathrm{MV}$. For example, can a basic residue such as lysine or arginine positioned to the N-terminal side of Trp approximate the N-terminal ammonium group that is known to stabilize the binding of cucurbit[n]urils to N-terminal aromatic peptides? Do bulky residues interfere sterically with binding? Small peptides are straightforward to synthesize and characterize in small numbers. Ideally, however, we would like to measure and compare the effects of varying the identity of the residues at positions neighboring the Trp binding site to all possible amino acids, and thus we need to synthesize and screen a library of peptides.

An interesting characteristic of the $\mathrm{Q} 8 \bullet \mathrm{MV} \bullet$ Trp system is its optical sensing capabilities. We and others have observed that Trp binding is accompanied by the growth of a new charge-transfer absorbance and the quenching of indole fluorescence $(36,41)$. Here we present an assay that uses these supramolecular and optical properties to compare in parallel the extent of binding of Q8 $\bullet \mathrm{MV}$ to a library of 104 Trp-containing peptides by comparing the relative extents of fluorescence quenching. Remarkably, we observe no significant effect of sequence context on Trp binding.

\section{Results and Discussion}

\subsection{Design}

The peptide library (Figure 2) was designed such that each peptide contained a tryptophan binding site at either an $\mathrm{N}$-terminal or non-terminal position in order to account for the expected difference in affinity due to the location of the Trp residue (42). The C-terminal position was not investigated because it is the lowest affinity site. The N-terminal Trp-containing peptides were tripeptides of sequence Trp-Var1-Var2, and the non-terminal Trp-containing peptides were pentapeptides of sequence $\operatorname{Var}_{1}-\operatorname{Var}_{2}-\operatorname{Trp}-\mathrm{Var}_{3}-\mathrm{Var}_{4}$. The variable (Var) positions were each varied among 18 genetically encoded amino acids (43) while holding 
the other position(s) constant with Ala residues. Ala was chosen as the spacer because its beta-methyl group is the largest sidechain fragment that represents the structures of the other amino acids (all except Gly). This design resulted in a library of 104 peptides (44). The peptide library was synthesized by parallel solid-phase synthesis on Rink amide resin (see Supporting Information).

\subsection{Parallel Peptide-Binding Assay}

The peptide-binding assay is based on the built-in optical sensing capability of the Q8 $\bullet \mathrm{MV} \bullet \operatorname{Trp}$ system, in which the binding of Trp to Q8 $\bullet \mathrm{MV}$ results in the quenching of indole fluorescence with a linear correlation between the observed extent of fluorescence quenching and the fraction of indole-containing compound bound to Q8 $\bullet \mathrm{MV}$ (calculated from the known binding affinity (36)). This property therefore allows us to estimate the fraction of Trp-containing peptides bound to Q8 $\bullet \mathrm{MV}$ (and thus the binding affinity) by comparing the fluorescence intensities of each peptide in the presence and absence of Q8 $\bullet \mathrm{MV}$ (Figure 3). Here we use this approach in the design of an assay to rapidly screen for the relative binding affinity of the library of 104 peptides to the Q8 $\bullet \mathrm{MV}$ complex. Therefore, this approach is amenable to parallel screening of peptide binding using a fluorescence plate reader.

Figure 4 shows the relative fluorescence quenching (45) of the 35 tripeptides (Figure $4 \mathrm{a}$ ) at $13 \mu \mathrm{M}$ and the 69 pentapeptides at $30 \mu \mathrm{M}$ (Figure $4 \mathrm{~b}$ ) in the presence of $50 \mu \mathrm{M} Q 8 \cdot \mathrm{MV}$ complex (Figure $4 \mathrm{~b}$ ). In the tripeptide series, the extent of fluorescence quenching was in the range $40 \%-49 \%$, with an average of $45 \%$ and a standard deviation of $2 \%$. In the pentapeptide series, the extent of fluorescence quenching was in the range $26 \%-47 \%$, with an average of $35 \%$ and a standard deviation of $3 \%$. In each series, the quenching values are remarkably consistent overall, which indicates that the sequence context of the Trp-binding site has little influence on the binding affinity. This is particularly true for the 
tripeptide series, with Trp at the N-terminal position. In the pentapeptide series, the range is larger due to the outliers Lys-Ala-Trp-Ala-Ala (1) with $28 \%$ quenching, Ala-Lys-Trp-Ala-Ala (2) with 47 \% quenching, and Leu-Ala-Trp-AlaAla with $26 \%$ quenching. In order to quantify the range of binding affinities represented by the outlier peptides, we measured the equilibrium association constant $\left(\mathrm{K}_{\mathrm{a}}\right)$ values for the sequence isomers $\mathbf{1}$ and $\mathbf{2}$ in complex with Q8 $\bullet \mathrm{MV}$.

\subsection{Equilibrium Binding Titrations}

Figure 5 shows fluorescence titrations of $Q 8 \bullet M V$ against a constant concentration of peptide for peptides 1 and 2 . The $K_{a}$ values were $6.2( \pm 0.3) \times 10^{3}$ $\mathrm{M}^{-1}$ for peptide 1 and $1.7( \pm 0.1) \times 10^{4} \mathrm{M}^{-1}$ for peptide 2 . The small relative binding affinity between these two peptides (2.7-fold, $\left.0.6 \mathrm{kcal} \mathrm{mol}^{-1}\right)$ is measurable but insignificant, and therefore these results further underscore the minimal effect of sequence context on binding to Trp-containing peptides. Using these values in addition to the affinity of Q8 for MV $\left(9 \times 10^{5} \mathrm{M}^{-1}\right)(36)$ we calculate the difference in the fraction of peptides 1 and 2 bound to Q8 $\bullet \mathrm{MV}$ to be $17 \%$, which is very similar to the observed difference in fluorescence quenching of $19 \%$, as expected. These results also demonstrate that the assay is sufficiently sensitive to report small differences in binding energies as relatively large differences in the extent of fluorescence quenching.

\subsection{Conclusions}

This study explores the effects of sequence context on the binding of Q8 $\bullet \mathrm{MV}$ to Trp-containing peptides. We observe that the identity of the amino acid residues at positions adjacent to the Trp-binding site, for both $\mathrm{N}$-terminal and non-terminal Trp, have little if any influence on the strength of interaction. This result is remarkable given the range of functional groups present in proximity to the Q8 portal, including sidechains with ammonium, carboxylate, and hydrophobic groups, all of which would be expected to influence the binding 
affinity via electrostatic, hydrophobic and/or steric interactions. Therefore, Q8 $\bullet$ MV should be able to bind Trp residues in a broad range of peptide sequence contexts with predictable binding affinities. This property may prove useful for targeting Trp residues commonly found at hotspots in protein-protein interactions (15) and for quantifying surface-exposed tryptophan residues. This study also demonstrates a powerful approach to the parallel screening of peptide interactions using a synthetic receptor using the convenient measurement of fluorescence intensities to estimate relative binding affinities. This approach would be compatible with a strategy for altering the binding properties of the receptor, $\mathrm{Q} 8 \bullet \mathrm{MV}$, by tailoring the structure of the viologen cofactor. We are currently exploring this direction and will report those results in due course. 


\section{Materials and Methods}

\subsection{Instrumentation}

UV-visible spectra were acquired at $25{ }^{\circ} \mathrm{C}$ using an Agilent 8453

spectrophotometer. Electrospray ionization mass spectrometry (ESI-MS) was performed on a Thermo LCQ DECA XP mass spectrometer with an electrospray ion source in the positive ion mode. Fluorescence quenching and titration experiments were carried out using a Tecan Infinite M200 Pro plate reader, with $280 \mathrm{~nm}$ excitation and $350 \mathrm{~nm}$ emission wavelengths, $5 \mathrm{~nm}$ excitation bandwidth, $20 \mathrm{~nm}$ emission bandwidth, and $20 \mu$ s integration time. The fluorescence spectra of Trp-Ala-Ala and Q8 $\bullet$ MV •Trp-Ala-Ala were collected on a PTI QM-4 spectrophotometer with $280 \mathrm{~nm}$ excitation wavelength, $3 \mathrm{~nm}$ excitation slit width, and $5 \mathrm{~nm}$ emission slit width.

\subsection{Materials}

The following compounds were of analytical purity grade and used without purification: (L)-Fmoc-Ala-OH, (L)-Fmoc-Arg-(Pbf)-OH, (L)-Fmoc-Asn(Trt)-OH, (L)-Fmoc-Asp(OtBu)-OH, (L)-Fmoc-Cys(Trt)-OH, (L)-Fmoc-Glu(OtBu)-OH, (L)Fmoc-Gln(Trt)-OH, (L)-Fmoc-Gly-OH, (L)-Fmoc-His(Trt)-OH, (L)-Fmoc-Ile-OH, (L)-Fmoc-Leu-OH, (L)-Fmoc-Lys(Boc)-OH, (L)-Fmoc-Met-OH, (L)-Fmoc-Phe-OH, (L)-Fmoc-Pro-OH, (L)-Fmoc-Ser(tBu)-OH, (L)-Fmoc-Thr(tBu)-OH, (L)-Fmoc$\operatorname{Trp}(\mathrm{Boc})-\mathrm{OH}$, (L)-Fmoc-Tyr(tBu)-OH, (L)-Fmoc-Val-OH, and O-(benzotriazol-1yl)-N,N, $\mathrm{N}^{\prime}, \mathrm{N}^{\prime}$-tetramethyluronium hexafluorophosphate (HBTU) (Peptides International); biotech-grade dimethyl formamide (DMF), diisopropylethylamine (DIEA), triisopropylsilane (TIS), trifluoroacetic acid (TFA), piperidine, anhydrous dichloromethane (DCM), and HPLC-grade acetonitrile (Sigma-Aldrich); and monobasic and dibasic sodium phosphate (VWR). Cucurbit[8]uril (Q8) was synthesized according to a published procedure (46). Water was obtained from a Barnstead Nanopure Infinity water system $(18 \mathrm{M} \Omega \mathrm{cm})$. 
A stock solution of $1.0 \mathrm{M}$ sodium phosphate buffer was adjusted to $\mathrm{pH} 7.0$ and sterile filtered. $10 \mathrm{mM}$ sodium phosphate buffer was made as needed by diluting the $1.0 \mathrm{M}$ stock and adjusting to $\mathrm{pH}$ 7.0. The concentration of methyl viologen was determined by UV spectroscopy $\left(\varepsilon_{257}=20,400 \mathrm{M}^{-1} \mathrm{~cm}^{-1}\right)$. The concentration of Q8 was standardized by calorimetric titration with methyl viologen.

\subsection{Peptide Synthesis}

Parallel fmoc solid-phase synthesis was carried out using SynPhase Rink amide Lantern resins from Mimotopes on $8 \mu \mathrm{mol}$ scale. The resins were mounted to pins in an $8 \times 12$ array (i.e., the "rack of resins") to match the spacing of a standard 96-well plate. Fmoc deprotection was accomplished by adding $500 \mu \mathrm{L}$ of $20 \%$ piperidine (v/v) in dimethylformamide (DMF) into each well of a 96 well deep-well block (Hamilton Research), and then seating the rack of resins into the wells of the block and allowing the reaction to shake at $120 \mathrm{RPM}$ for 1 hour $25^{\circ} \mathrm{C}$ in an orbital shaker (e.g., a shaking bio-incubator). The rack of resins was then rinsed thoroughly according to the following procedure: 1) two baths of DMF and dichloromethane (DCM) were set up; 2) the rack of resins was rinsed thoroughly and sequentially by dipping first into the two DMF baths, and then into the two DCM baths, with gentle flicking of the rack between each rinse to remove excess solution; and 3) the rack of resins was removed and allowed to air dry for approximately 20 minutes.

To prepare benzotriazoyl-activated amino acid solutions for coupling, we used 12 equivalents $(96 \mu \mathrm{mol})$ of fmoc amino acid, 12 equivalents $(96 \mu \mathrm{mol})$ of diisopropyl ethylamine (DIEA), and 10 equivalents $(80 \mu \mathrm{mol})$ of HBTU (based on a limiting quantity of $8 \mu \mathrm{mol}$ resin) dissolved in $0.5 \mathrm{~mL}$ of DMF. Amino acid solutions were scaled to the number of couplings needed per amino acid in the entire library so that only one stock solution of each amino acid needed to be 
prepared. The coupling reaction was accomplished by adding $0.5 \mathrm{~mL}$ of the activated amino acid solution into a well of a clean 96-well deep-well block and then seating the resin rack into the block. The reaction shook (120 RPM) for 3 hours at $25^{\circ} \mathrm{C}$, and the resins were then rinsed as described above.

Cycles of deprotection and coupling continued in this manner until the desired sequence was obtained. After the final fmoc deprotection, the resins were rinsed as described above. Cleavage of the peptides from the resins was carried out by adding $600 \mu \mathrm{L}$ of cleavage solution (95\% TFA, $2.5 \% \mathrm{H}_{2} 0,2.5 \%$ TIS), into each well of a clean 96-well deep-well block, seating the resin rack into it, and letting the reactions shake at $120 \mathrm{RPM}$ for 1 hour at $25^{\circ} \mathrm{C}$. The resin rack was removed, and the cleavage mixture was evaporated overnight with steady airflow over the plate. After the TFA was removed completely, $800 \mu \mathrm{L}$ of nanopure water was added to each well, and the block was heated at $60^{\circ} \mathrm{C}$ for 30 min to dissolve the peptides. The peptide solutions were transferred to $1.5 \mathrm{~mL}$ Eppendorf tubes and lyophilized to dryness. The dry peptides were resuspended in $1.0 \mathrm{~mL}$ of $10 \mathrm{mM}$ phosphate buffer, heated for 15 minutes at 60 ${ }^{\circ} \mathrm{C}$, and sonicated if necessary to solubilize the peptides. A random subset of six peptides was tested for purity, quantity, and identity (See Supporting Information). The average purity, as determined by analytical HPLC, was $78 \%$. The average concentration, as determined by UV-spectroscopy $\left(\varepsilon_{280}=5500 \mathrm{M}^{-1}\right.$ $\mathrm{cm}^{-1}$ ) was $2.1 \mathrm{mM}$ for the tripeptides and $4.8 \mathrm{mM}$ for the pentapeptides, and thus the peptide recoveries from synthesis were $26 \%$ for the tripeptides and $60 \%$ for the pentapeptides. The identities of the peptides were confirmed by ESI-MS. The peptide solutions were stored at $4{ }^{\circ} \mathrm{C}$.

\subsection{Fluorescence Quenching Experiments}

Q8 $\bullet \mathrm{MV}$ solutions were prepared by dissolving MV in $10 \mathrm{mM}$ sodium phosphate buffer, $\mathrm{pH}$ 7.0, and determining the concentration of the solution by UV 
spectroscopy $\left(\varepsilon_{257}=20,400 \mathrm{M}^{-1} \mathrm{~cm}^{-1}\right)$. This solution was adjusted to $100 \mu \mathrm{M}$ in the same buffer and added to an equimolar quantity of dry $\mathrm{Q} 8$. The $\mathrm{Q} 8 \bullet \mathrm{MV}$ mixture was solubilized by mixing and brief ultrasonication followed by heating at $60^{\circ} \mathrm{C}$ for 15-20 minutes. The resulting colorless solution was cooled to room temperature and sterile-filtered $(0.4 \mu \mathrm{m}$, Teflon).

Fluorescence experiments were carried out in Corning 96-well, black, flatbottomed plates. Peptides sample solutions were prepared by mixing $50 \mu \mathrm{L}$ of peptide stock solution with $50 \mu \mathrm{L}$ of $10 \mathrm{mM}$ phosphate buffer. Peptide $+\mathrm{Q} 8 \bullet \mathrm{MV}$ solutions were prepared by mixing $50 \mu \mathrm{L}$ of peptide stock solution with $50 \mu \mathrm{L}$ of $100 \mu \mathrm{M}$ Q8 $\bullet \mathrm{MV}$ solution. The peptide stock solutions were $26 \mu \mathrm{M}$ for tripeptides and $60 \mu \mathrm{M}$ for pentapeptides. Therefore, the final concentrations were $13 \mu \mathrm{M}$ tripeptide or $30 \mu \mathrm{M}$ pentapeptide, and $50 \mu \mathrm{M}$ Q8 $\bullet \mathrm{MV}$ for samples that contain Q8 $\bullet \mathrm{MV}$. The solutions were mixed by pipetting before reading the fluorescence intensity on a fluorescence plate reader. The extent of fluorescence quenching (\%Quenched) was determined as the fraction of fluorescent emission intensity (F) lost upon treatment with Q8・MV:

$$
\% \text { Quenched }=\frac{\left(F_{\text {peptide }} F_{\text {peptide } Q 88 \cdot M V}\right)}{F_{\text {peptide }}}
$$

\subsection{Fluorescence Titrations}

Fluorescence titrations were carried out on peptides $\mathbf{1}$ and $\mathbf{2}$. The peptides were quantified UV spectroscopy $\left(\varepsilon_{280}=5500 \mathrm{M}^{-1} \mathrm{~cm}^{-1}\right)$. In the final samples for measurement, the concentration of peptide was held constant at $0.121 \mathrm{mM}$ for peptide 1 and $0.206 \mathrm{mM}$ for peptide 2 , while the concentration of Q8 $\bullet \mathrm{MV}$ was varied over the range 0-1.4 mM. Fluorescence intensity values were obtained using the plate reader and plotted versus the total peptide concentration. Each plot was fit to a simple binary equilibrium model using a nonlinear regression to obtain equilibrium association constant values. 


\section{Acknowledgment}

Financial Support from the National Science Foundation (CHE-0748483), the Welch Foundation (W-1640), the Henry Dreyfus Teacher-Scholar Awards

Program, and Trinity University is gratefully acknowledged. Omar Ali was a Beckman Scholar. 


\section{References}

(1) Dougan, D. A.; Micevski, D.; Truscott, K. N. Biochim. Biophys. Acta 2011, 1823, 83-91.

(2) Hunter, T. Methods Enzymol. 1991, 200, 3-37.

(3) Handbook of Proteolytic Enzymes, Rawlings, N.; Salvesen, G., Eds. Academic Press, London, 2013.

(4) McGovern, R. E.; Fernandes, H.; Khan, A. R.; Power, N. P.; Crowley, P. B. Nature Chem. 2012, 4, 527-533.

(5) Chinai, J. M.; Taylor, A. B.; Ryno, L. M.; Hargreaves, N. D.; Morris, C. A.; Hart, P. J.; Urbach, A. R. J. Am. Chem. Soc. 2011, 133, 8810-8813.

(6) Nguyen, H. D.; Dang, D. T.; van Dongen, J. L. J.; Brunsveld, L. Angew. Chem. Intl. Ed. 2010, 49, 895-898.

(7) Rekharsky, M. V.; Yamamura, H.; Ko, Y. H.; Selvapalam, N.; Kim, K.; Inoue, Y. Chem. Commun. 2008, 2236-2238.

(8) Hayashida, O.; Ogawa, N.; Uchiyama, M. J. Am. Chem. Soc. 2007, 44, 1369813705.

(9) Wehner, M.; Janssen, D.; Shafer, G.; Schrader, T., "Sequence-Selective Peptide Recognition with Designed Molecules" Eur. J. Org. Chem. 2006, 138-153.

(10) Tashiro, S.; Tominaga, M.; Kawano, M.; Therrien, B.; Ozeki, T.; Fujita, M. J. Am. Chem. Soc. 2005, 127, 4546-4547.

(11) Wright, A. T.; Anslyn, E. V. Org. Lett. 2004, 6, 1341-1344.

(12) C. Schmuck, L. Geiger: "Carboxylate Binding by Guanidiniocarbonyl Pyrroles: From Self-Assembly to Peptide Receptors." Curr. Org. Chem. 2003, 7, 1485-1502.

(13) Ojida, A.; Mito-oka, Y.; Inoue, M.; Hamachi, I. J. Am. Chem. Soc. 2002, 124, 6256-6258.

(14) Braxmeier, T. M.; Demarcus, M.; Fessmann, T.; McAteer, S.; Kilburn, J. D. Chemistry 2001, 7, 1889-1898.

(15) Peczuh, M. W.; Hamilton, A. D. Chem. Rev. 2000, 100, 2479-2493.

(16) Sirish, M.; Schneider, H.-J. Chem. Comm. 1999, 907-908.

(17) Breslow, R.; Yang, Z.; Ching, R.; Trojandt, G.; Odobel, F. J. Am. Chem. Soc. 1998, 120, 3536-3537.

(18) Lagona, L.; Mukhopadhyay, P.; Chakrabarti, S.; Isaacs, L. Angew. Chem. Int. Ed. 2005, 44, 4844-4870

(19) Masson, E.; Ling, X.; Joseph, R.; Kyeremeh-Mensah, L.; Lu, X. RSC Adv. 2012, 2, 1213-1247.

(20) Lee, J. W.; Samal, S.; Selvapalam, N.; Kim, H.-J.; Kim, K. Acc. Chem. Res. 2003, 36, 621-630.

(21) Ko, Y. H.; Kim, E.; Hwang, I.; Kim, K. Chem. Commun. 2007, 1305-1315.

(22) Appel, E. A.; Loh, X. J.; Jones, S. T.; Biedermann, F.; Dreiss, C. A.; Scherman, O. A. J. Am. Chem. Soc. 2012, 134, 11767-11773. 
(23) Biedermann, F.; Scherman, O. A. J. Phys. Chem. B 2012, 116, $2842-2849$.

(24) Rauwald, U.; del Barrio, J.; Loh, X. J.; Scherman, O. A. Chem. Commun. 2011, 47, 6000-6002.

(25) Nguyen, H. D.; Dang, D. T.; van Dongen, J. L. J.; Brunsveld, L. Angew. Chem. Int. Ed. 2010, 49, 895-898.

(26) Pemberton, B. C.; Barooah, N.; Srivatsava, D. K.; Sivaguru, J. Chem. Commun. 2010, 46, 225-227.

(27) Rauwald, U.; Scherman, O. A. Angew. Chem. Int. Ed. 2008, 47, 3950-3953.

(28) Ling, Y.; Wang, W.; Kaifer, A. E. Chem. Commun. 2007, 610-612.

(29) Moon, K.; Grindstaff, J.; Sobransingh, D.; Kaifer, A. E. Angew. Chem. Int. Ed. 2004, 43, 5496-5499.

(30) Ramalingam, V.; Kwee, S. K.; Ryno, L. M.; Urbach, A. R. Org. Biomol. Chem. 2012, 10, 8587-8589.

(31) Ramalingam, V.; Urbach, A. R., Org. Lett. 2011, 13, 4898-4901.

(32) Biedermann, F.; Ruwald, U.; Cziferszky, M.; Williams, K. A.; Gann, L. D.; Guo, B. Y.; Urbach, A. R.; Bielawski, C. W.; Scherman, O. A. Chem. Eur. J. 2010, 87, 13716-13722.

(33) Reczek, J. J.; Kennedy, A. A.; Halbert, B. T.; Urbach, A. R. J. Am. Chem. Soc. 2009, 131, 2408-2415.

(34) Rajgariah, P.; Urbach, A. R. J. Incl. Phenom. Macrocyc. Chem. 2008, 62, 251254.

(35) Heitmann, L. M.; Taylor, A. B.; Hart, P. J.; Urbach, A. R., J. Am. Chem. Soc. 2006, 128, 12574-12581.

(36) Bush, M. E.; Bouley, N. D.; Urbach, A. R. J. Am. Chem. Soc. 2005, 127, 14511-14517.

(37) Li, H.; Xie, H.; Cao, Y.; Ding, X.; Yin, Y.; Li, G. Anal. Chem. 2013, 85, 10471052.

(38) Ding, X.; Li, H.; Xie, H.; Huang, Y.; Hou, Y.; Yin, Y.; Li, G. Biosens. Bioelectron. 2013, 47, 75-79.

(39) Cziferszky, M.; Biedermann, F.; Kalberer, M.; Scherman, O. A. Org. Biomol. Chem. 2012, 10, 2447-2452.

(40) Tian, F.; Cziferszky, M.; Jiao, D.; Wahlström, K.; Geng, J.; Scherman, O. A. Langmuir 2011, 27, 1387-1390.

(41) U.S. Patent: Kim, K.; Kim, J.; Jung, I.-S.; Kim, S.-Y.; Lee, E.; Kang, J.-K. Pohang University of Science and Technology Foundation, 2000.

(42) Based on prior work (36), equilibrium association constant $\left(\mathrm{K}_{\mathrm{a}}\right.$ values are $\sim 10^{5}$ for $\mathrm{N}$-terminal and $\sim 10^{4}$ for non-terminal peptides.

(43) Tryptophan and cysteine (Cys) were not included in the variation because the presence of a second Trp binding site and fluorescent marker would complicate the analysis, and because Cys-containing peptides spontaneously dimerize.

(44) Leaving out the replicate Trp-Ala-Ala and Ala-Ala-Trp-Ala-Ala peptides (i.e., $\operatorname{Var}_{1}=\operatorname{Var}_{2}=\mathrm{Ala}$ ), there are 35 tripeptides and 69 pentapeptides. 
(45) The extent of fluorescence (F) quenched (\%Quenched) was calculated from Equation 1.

(46) Day, A.; Arnold, A. P.; Blanch, R. J.; Snushall, B. J. Org. Chem. 2001, 66, 8094-8100. 


\section{Figure Captions}

Figure 1. (top) Equilibria involved in the formation of the Q8 $\bullet \mathrm{MV} \bullet$ Trp complex. (bottom) Chemical formulas of the constituents.

Figure 2. Library of (left) tripeptides and (right) pentapeptides used in this study. The variable (Var) positions were varied to 18 amino acids (the canonical 20 minus Trp and Cys).

Figure 3. Fluorescence spectral overlay of Trp-Ala-Ala in the absence and presence of Q8 $\bullet \mathrm{MV}$. All species were at $50 \mu \mathrm{M}$ in a buffer of $10 \mu \mathrm{M}$ sodium phosphate, pH 7.0.

Figure 4. Extent of fluorescence quenching of samples containing (a) $13 \mu \mathrm{M}$ tripeptide or (b) $30 \mu \mathrm{M}$ pentapeptide in the presence of $50 \mu \mathrm{M}$ Q8 $\bullet \mathrm{MV}$ at $25^{\circ} \mathrm{C}$ in $10 \mathrm{mM}$ sodium phosphate, $\mathrm{pH}$ 7.0. The identity of the variable position is indicated along the Y-axis, and the location of the variable positions within the peptides are indicated by the legends. Average values of at least three experiments are plotted. Error bars indicate the standard deviation.

Figure 5. Titration of Q8 $\bullet \mathrm{MV}$ against a constant concentration of peptides $\mathbf{1}$ $(0.121 \mathrm{mM})$ and $2(0.206 \mathrm{mM})$. Relative fluorescence emission intensity values are plotted. The line indicates the best fit to binary equilibrium binding model. Equilibrium association constant values, derived from the fits, are shown. 